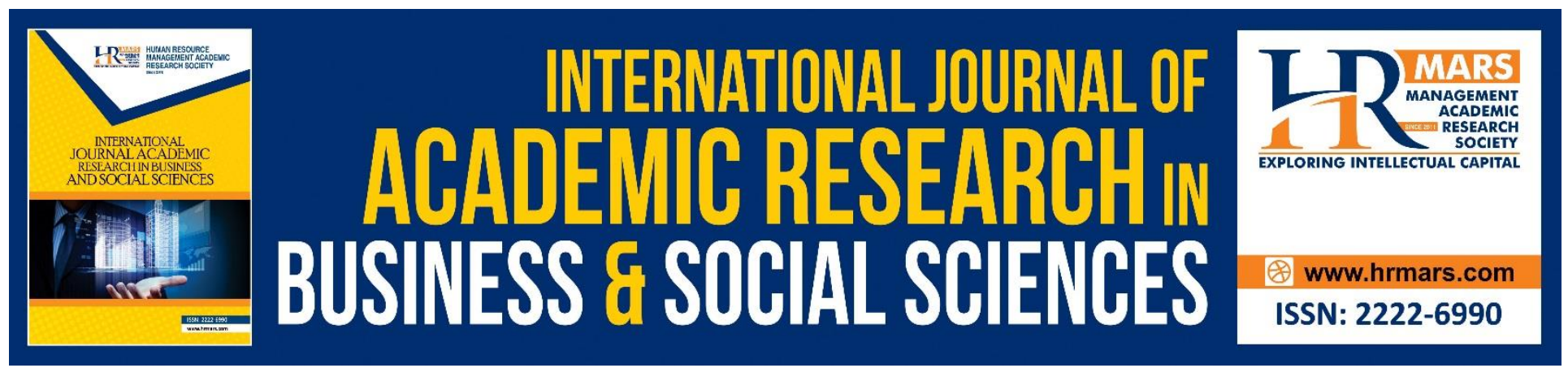

\title{
Conceptual Analysis on Performance Measurement Used in SMEs Research: The Effectiveness of Firm's Overall Performance
}

Norfadzilah Rashid, Wan Nur Syahida Wan Ismail, Mohd Shaari Abd Rahman, Asyraf Afthanorhan

To Link this Article: http://dx.doi.org/10.6007/IJARBSS/v8-i11/5199

DOI: $10.6007 /$ IJARBSS/v8-i11/5199

Received: 25 Oct 2018, Revised: 30 Nov 2018, Accepted: 04 Dec 2018

Published Online: 08 Dec 2018

In-Text Citation: (Rashid, Ismail, Rahman, \& Afthanorhan, 2018)

To Cite this Article: Rashid, N., Ismail, W. N. S. W., Rahman, M. S. A., \& Afthanorhan, A. (2018). Conceptual Analysis on Performance Measurement Used in SMEs Research: The Effectiveness of Firm's Overall Performance. International Journal of Academic Research in Business and Social Sciences, 8(11), 1401-1412.

Copyright: (C) 2018 The Author(s)

Published by Human Resource Management Academic Research Society (www.hrmars.com)

This article is published under the Creative Commons Attribution (CC BY 4.0) license. Anyone may reproduce, distribute, translate and create derivative works of this article (for both commercial and non-commercial purposes), subject to full attribution to the original publication and authors. The full terms of this license may be seen at: http://creativecommons.org/licences/by/4.0/legalcode

Vol. 8, No. 11, 2018, Pg. 1401 - 1412

http://hrmars.com/index.php/pages/detail/IJARBSS

JOURNAL HOMEPAGE

Full Terms \& Conditions of access and use can be found at http://hrmars.com/index.php/pages/detail/publication-ethics 


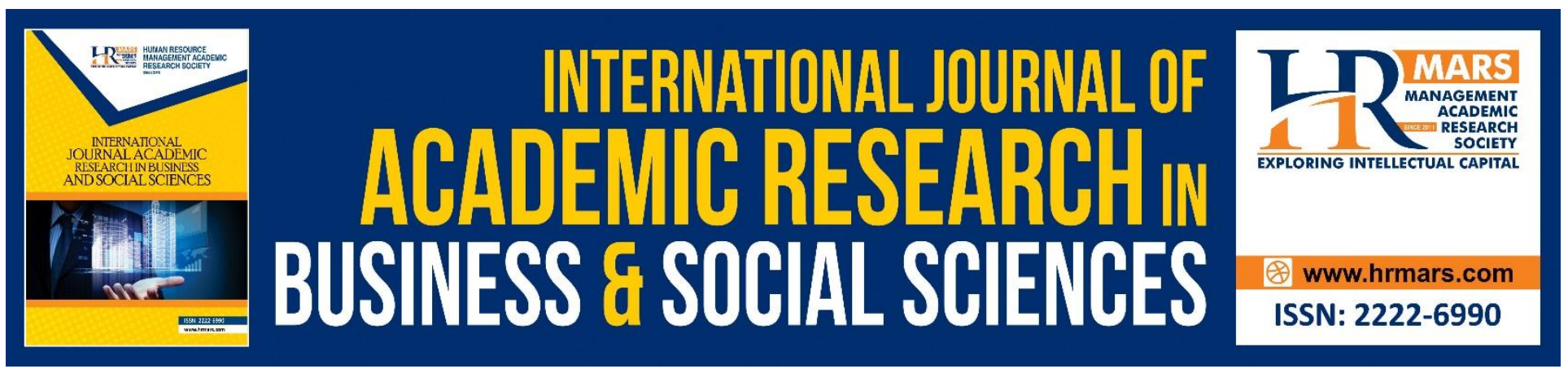

\title{
Conceptual Analysis on Performance Measurement Used in SMEs Research: The Effectiveness of Firm's Overall Performance
}

\author{
${ }^{1}$ Norfadzilah Rashid, ${ }^{2}$ Wan Nur Syahida Wan Ismail, ${ }^{3}$ Mohd Shaari \\ Abd Rahman, ${ }^{4}$ Asyraf Afthanorhan \\ ${ }^{2,3}$ School of Maritime Business and Management,Universiti Malaysia Terengganu, 21030 Kuala \\ Terengganu, Malaysia
}

${ }^{1}$ Faculty of Economic and Management Sciences Universiti Sultan Zainal Abidin, 21300 Kuala Nerus, Malaysia

Corresponding Author:w.nur@umt.edu.my

\begin{abstract}
The purpose of this paper is to review the literatures related to small-and-medium enterprises (SMEs) and analyze the measurement used for firm performance. The finding from the analysis showed most researchers categorized performance into two broad categories, financial and non-financial measures. However, arguments have been upsurge among researchers as both measures has certain limitations. To exit the dispute, some researchers proposed the effectiveness of using firm's overall performance. However, whatever type of measurement choose, it should depends on the objective of the research and the nature of the industry. Therefore, the analysis in this paper is hoped to give insights for researchers in determining the performance measures that most appropriate to be used in their research.
\end{abstract}

Keywords: Small and medium-sized enterprises (SMEs), Non-Financial Measures, Performance

\section{Introduction}

Small and medium-sized enterprises (SMEs) are large heterogeneous groups of businesses usually operating in the service, trade, agriculture and manufacturing sectors. The importance of SMEs in economic development among the world's major economies has long been known. It has been widely accepted that SMEs not only play a role in the business environment, but also are crucial to the stability of a country's economy (Afthanorhan, Awang, Rashid, Foziah, \& Ghazali, 2019). (Afthanorhan, Awang, Salleh, Ghazali, \& Rashid, 2018) mentioned that SMEs also create job opportunities for people that lead to income generation and distribution. In many countries, SMEs constitute more than $90 \%$ of business establishments, for example, in the United State $99.7 \%$ (Shams et al., 2018), in Australia and Denmark 96 to 99\% (N. Rashid, Fara, et al., 2018), in Singapore 99\%, in 
INTERNATIONAL JOURNAL OF ACADEMIC RESEARCH IN BUSINESS AND SOCIAL SCIENCES

Vol. 8, No. 11, Nov, 2018, E-ISSN: 2222-6990 @ 2018 HRMARS

Thailand 99.5\%, in New Zealand 97\% , in Philippines 99.6\% and in Malaysia 98.5\%. Therefore, for the role of SMEs as major economic players and a potent source of national, regional and local economic growth in many countries (N. Rashid, Muhmad, et al., 2018), SMEs performance appeared to be an issue which has been attracted many researchers.

\section{Performance Definition}

In extant literature, the term performance has numerous different definitions. (Salleh, Noor, et al., 2018) define performance as the ability of an object to produce results in a dimension determined by a priori, in relation to a target. When referring to accounting terms, (Usop et al., 2018) define performance as the relationship of the income and expenses of an enterprise, as reported in the income statement.

For organizations, (Norliana, Fakhrul Anwar, Wan Norhayate, Norfadzilah, \& Asyraf, 2018) refer to organizational performance as an indicator that measures how well an organization accomplishes its objectives. Organizational performance, which is also widely termed as firm's performance, was defined by (Zainol et al., 2018) as organizational effectiveness in terms of its financial and operational performance. (Kurniasih et al., 2018) defines performance as the outcome of firm operation. (Johari, Rashid, \& Yazid, 2018) recommends performance as evaluating how well organizations are managed and the value they deliver for customers and other stakeholders. This definition encourages people involved in performance measurement to consider the extent to which organizations measure the value they convey to their customers and whether it covers the core aspects of how performance is managed (M. Ismail et al., 2018).

Some studies relate the performance as a success. The terms "success" and "performance" are often very closely linked and are sometimes even used synonymously in many studies. According to (Hamid et al., 2018) the performance of small businesses has been related to their success or failure. Therefore, higher performance is generally interpreted as representing a more successful firm, and a lower performance meaning a less successful firm. Moreover, in (Sabiu et al., 2018) study, the relationship between succession issues and business performance was empirically investigated. The result indicated that the successor development dimension was an effective predictor of business performance.

\section{Financial versus Non-financial Measures of Firm's Performance}

Firm's performance has been captured in the literatures using a variety of indicators. It could, however, be categorized into two broad categories, financial and non-financial measures. Some researchers used different terms, such as financial and operational performance measures (Johari, Tarmizi, Mohd, \& Rashid, 2018), finance and efficiency and short and long-term measures. Shortterm measures are normally based on the financial returns, while long-term measures are normally based on the non-financial returns (Salleh, Ibrahim, et al., 2018). Whatever terms that are used, it still revolves around the financial and non-financial criteria. 
Financial performance indicators are a set of variables, which usually can show the firm's capability in making profits (Zain, Abdullah, \& Rashid, 2018) while non-financial indicators are a set of variables that are not measured by financial systems (N. M. N. N. M. Rashid, Rasit, Syazwani, Hamid, \& Yazid, 2017). In particular, researchers employ financial measures such as sales/turnover, profit, return on assets (ROA), return on investments (ROI), return on equity (ROE), return on capital employed (ROCE), return on shareholder's equity (ROSE), growth, net profit and gross profit. All of these indicators relate to the firm's capability in making profits. As for the non-financial performance measures, the measures include number of employees, competitive position, market share, satisfaction, number of customers, market area, number of outlets, innovation and relative quality, which are not measured by financial systems. Typically, they are the special indicators that are used in certain circumstances depending on the nature and objectives of the study.

Using either financial or non-financial measures has long been an argument among researchers. (Yazid, Jais, et al., 2017) suggested that a financial criterion is an adequate tool to measure performance due to its contribution towards economic development. SMEs play a very important role in the economies of both developed and developing countries, representing well over 90 percent of all manufacturing enterprises in the world. (N. M. N. N. M. Rashid, Muhmad, Hamid, Rasit, \& Noor, 2017) however suggested this role depends on the financial performance of each enterprise.

Besides its contribution to the economy, profits and financial rewards are also a desirable objective of SME owners. This was supported by statements from several of the interviewees in (N. M. N. N. M. Rashid, Rasit, et al., 2017) study who mentioned making money as being their primary criterion for judging the success of a business. Therefore, it is clear that the primary objective of the firm is to obtain superior financial performance (Yazid, Ariffin, et al., 2017).

Another reason for adopting the financial criterion as a performance measure is that businesses are only viable if they are financially solvent (N. M. N. N. M. Rashid, Malik, Noor, Sanusi, \& Hamid, 2017) noted that all businesses must be financially viable on some level in order to continue to exist.

Financial performance was also adopted as it underpins and is implicit in both short and long-term measures. In their study, (W. S. W. Ismail, Ali, \& Rashid, 2017) used financial returns and firm growth as the principal performance of short and long-term performance measures. For the above reasons, financial performance was adopted by the researchers in measuring performance of the firms.

(Amirah, Amin, Muda, Talaat, \& Rashid, 2017) suggested that financial performance has generally been popular due to the ease with which it can be administered and applied since it is very much a 'hard' measure. The 'hard' measure is easier to understand and can be used in a comparative manner against existing data and as a benchmark for future measures.

Some researchers however argued that using financial criteria as a performance measure would not adequately cover the varied goals of owner-managers in small businesses. This is in line with claimed by (Chi \& Ziebart, 2017) that some businesses have no interest in growth, implying that financial gain 
is not their primary or only motivation, it must therefore be other non-financial criteria that these owner-managers use to measure their success. According to (Lassoued, Ben Rejeb Attia, \& Sassi, 2017), financial measures do not show the long-term advantage actions, thus non-financial measures are recommended because they are believed to be leading indicators of financial performance. Managers act and make decisions based on the effect of non-financial measures such as innovation, quality, productivity, and customer satisfaction, which ultimately leads to future financial performance (Dimovski, Ratcliffe, \& Keneley, 2017).

(Huseynov, Sardarli, \& Zhang, 2017) suggested that the performance of any enterprise can only be assessed with reference to its objectives and in many cases, small businesses are not run entirely, or even primarily, for financial reasons and therefore could be defined in a number of ways. For that reason, (Sundvik, 2017) noted that obtaining measures of performance for SMEs was notoriously difficult.

On the other hand, (Martins, 2017) concluded that the assumption of using non-financial measures is usually after a certain level of financial security has already existed or established. Even though the objective during start-up was not primarily for financial reasons, once the business is established, increasing financial rewards must be the aim to keep the business alive. Whatever goals aspired by the entrepreneurs, it will only be fulfilled if the business continues to exist. This directs the ownermanagers to focus their attention on the financial measures.

It has also been argued by researchers that non-financial measures of success used by business owners are also subjective and personally defined and are consequently more difficult to be quantified since non-financial measures are based on criteria that are personally determined by the individual business owner. However, (AbRahman, Omar, Rashid, \& Ramli, 2016) argued that although financial measures are objective, simple and easy to understand and compute, but in most cases, they suffer from being historical and are not readily available in the public domain, especially the financial data of SMEs.

\section{Firm's Overall Performance}

Previous discussions expressed that financial and non-financial measures have certain limitations. Hence, (N. M. N. N. M. Rashid, Noor, Matsuki, AbRahman, \& Omar, 2016) have suggested an effective performance measurement system ought to cover all indicators of performance that are relevant to the existence of an organization. This means that any performance measurement system should be based on a holistic approach, which ought to include both financial and non-financial measures. A possible way forward is to apply the non-financial measures as supplementary to the financial measures or use both in combination (Riwayati, Markonah, \& Siladjaja, 2016). The combination of these two measures will help the owner-managers to gain a wider perspective on measuring and comparing their performances, in particular the extent of effectively and efficiently utilizing the resources, competitiveness and readiness to face growing external pressures, including globalization. 
Another explanation for using financial and non-financial performance measures is that when these measures are incorporated in the same model, managers can survey performances in several areas simultaneously in order to enable efficient strategic decision-making. This gives a better insight on the various aspects of SME's performance. Furthermore, (Khan, Hussain, \& Mehmood, 2016) stressed that when combining non-financial information and financial information, it can contribute to the prediction of the future value of the firm. This is because the combination sends a robust and comprehensive set of performance signals ( $N$. Rashid, Muhmad, et al., 2018). Therefore, combining non-financial measures and financial measures makes better evaluation of firm's performance.

Overall, the firm's financial performance measure was adopted by the researchers since it have been found to be highly correlated with non-financial measures of firm's performance. The non-financial performance is related to reality and concerned with causes while financial performance is related to the effect. For example, profit and other financial measures indicate the effects of non-financial activities and achievements, while factors of customer satisfaction, employee turnover and organization's innovation and improvement activities are thought to be the drivers of future financial function (N. Rashid, Muhmad, et al., 2018). Therefore, the use of financial and non-financial measures in a combination or termed as firm's overall performance seems more effective in measuring the real performance of the firm. For that reason, the overall performance has been a choice of many other studies (Liu, 2018; N. Rashid, Muhmad, et al., 2018; Salleh, Ibrahim, et al., 2018).

\section{Objective versus Subjective Measures}

Expanding the financial versus non-financial data, the literatures then made further distinction between the objective and the subjective measures of performance data. Some researchers however used different terms when referring to objective and subjective measures. (Zain et al., 2018) classified performance as quantitative and qualitative data. (Yazid, Jais, et al., 2017) referred to performance specifically as hard and soft. Hard is equal to objective measures and soft is equal to subjective measures. (N. M. N. N. M. Rashid, Muhmad, et al., 2017) categorized them as accounting and subjective measures. Earlier, (N. M. N. N. M. Rashid, Harman, et al., 2017) named objective and subjective measures as objective and perceptual measures.

According to (W. S. W. Ismail et al., 2017), objective data is based on some established system such as internal accounting, or systematic tracking by external agencies while perceptual measures are the judgments made by executives. These two approaches could be obtained through primary or secondary data. Primary data is the data that is collected directly from the target organizations while secondary data is collected from sources external to target organizations (Chi \& Ziebart, 2017).

In other words, although the different methods of categorization varied in their terminology, essential components of all categorization methods were either related to the actual figures or based on entrepreneur perception. Self-rating-success (SRS) is one of the important criteria in subjective measure. SRS is obtained by asking the owners to rate their own success or performance on a scale from 1 (not very successful) to 5 (very successful). (Lassoued et al., 2017) however use a scale until 10 (very successful). Subjective measures could also be rated based on self-evaluated opinions of 
firms elicited using questionnaires (Dimovski et al., 2017). The scale used is from 1 (very disagree) to 5 (very agree).

Subjective measures would be preferred of some researchers due to the difficulty in obtaining the objective data (Huseynov et al., 2017) stated that as most small firms are privately owned, it is unlikely that the owner-managers will be willing to provide detailed accounting data on the firm's performance. As such, many researchers described an objective data as sensitive, confidential and difficult to obtain from the respondents (Sundvik, 2017). Furthermore, in SMEs, the objective financial data may not be available as the SMEs are not required to publish their annual reports. Therefore, owner-manager's subjective evaluations were shown to be successful performance measures. The example of subjective financial measures such as "for the past 3 years, my profit is increased" and subjective non-financial measures such as "for the past 3 years, the market area of my product is wider".

The subjective measure has also been the choice when overcoming a problem that uses a sample containing a variety of industries. When looking at the performance of different industries, measuring based on the financial figures could be unfair since different industries face different costs and produce different profit margins. (N. M. N. N. M. Rashid, Noor, \& Mastuki, 2015) stressed that comparing the objective financial data obtained for the small business in different industries could be misleading. Therefore, for the multi-industry comparison, subjective measures are more flexible and useful. For these and other reasons, some researchers (Ghadas, Ismail, Aziz, \& Rahman, 2015) suggested that subjective measures of performance are better than objective measures when assessing the SME's performance.

Although some researchers preferring subjective measures over objective data, it would seem to be the simplest way to assess performance (Sax \& Torp, 2015). Furthermore, since subjective measures of performance are based on the owner's perception, they increase the possibility of measurement error and the potential for bias (Zhang, 2015). Therefore, if researchers limit themselves to a single industry, the objective performance measure may be more meaningful. (Kraft, 2015) considered to use objective performance as it represents the narrowest conception of business performance.

Nonetheless, some researchers adopted subjective measures since it has been found to be highly correlated with objective measures of firm's performance (Al-khazaleh, Wadi, \& Ababneh, 2015).This suggests that although objective and subjective measures are not identical, the objective measures do constitute a key element of the respondents' subjective assessments. For (Geng, Bose, \& Chen, 2015), subjective measures were preferred rather than objective measures because subjective measures have been shown to capture a broad concept of firm's performance.

\section{Conclusion}

As a conclusion based on the above discussions, the major goals of the study must be first understood before the performance measure can be assessed. Furthermore, the unique nature of the industry is also important to be considered in the selection of performance measures (Jiang, Habib, \& Zhou, 
INTERNATIONAL JOURNAL OF ACADEMIC RESEARCH IN BUSINESS AND SOCIAL SCIENCES

Vol. 8, No. 11, Nov, 2018, E-ISSN: 2222-6990 @ 2018 HRMARS

2015). In other words, the preferred performance measure depends on the objective of the research. This is in agreement with suggestions by (Toerien \& Marcus, 2014) which stated that financial or nonfinancial measure was not actually the issue. Researchers should conceptualized and measured performance using many schemes, depending upon their research questions, disciplinary focus, and data availability. In addition, for those that decide to represents a wider conception of business performance, the use of firm's overall performance could be the finest solution.

\section{References}

AbRahman, N. A., Omar, N., Rashid, N. M. N. N. M., \& Ramli, A. (2016). Improving Employees Accountability and Firm Performance through Management Accounting Practices. Procedia Economics and Finance, 35(16), 92-98. https://doi.org/10.1016/S2212-5671(16)00013-7

Afthanorhan, A., Awang, Z., Rashid, N., Foziah, H., \& Ghazali, P. L. (2019). Assessing the effects of service quality on customer satisfaction. Management Science Letters, 9(1), 13-24. https://doi.org/10.5267/j.msl.2018.11.004

Afthanorhan, A., Awang, Z., Salleh, F., Ghazali, P. L., \& Rashid, N. (2018). The effect of product quality, medical price and staff skills on patient loyalty via cultural impact in medical tourism. Management Science Letters, 8, 1421-1424. https://doi.org/10.5267/j.msl.2018.10.004

Al-khazaleh, A. M. H., Wadi, S. Al, \& Ababneh, F. (2015). Wavelet Transform Asymmetric Winsorized Mean In Detecting Outlier Values. Far East Journal of Mathematical Sciences, 96(3), 339-351.

Amirah, N. A., Amin, A., Muda, S., Talaat, W. I. W., \& Rashid, N. M. N. N. M. (2017). Relationship Between Behavioral Aspects and Safety Culture in the Peninsular Malaysia Manufacturing Industry. World Applied Sciences Journal, 35(9), 1880-1884. https://doi.org/10.5829/idosi.wasj.2017.1880.1884

Chi, Y.-H., \& Ziebart, D. A. (2017). Audit quality and attributes of management earnings forecasts. Review of Accounting and Finance, 16(4), 406-423. https://doi.org/10.1108/RAF-01-2015-0003

Dimovski, B., Ratcliffe, C., \& Keneley, M. (2017). Another piece of the puzzle: REIT IPO underpricing after the financial crisis. Journal of Property Investment \& Finance, 35(3), 264-276. https://doi.org/10.1108/JPIF-07-2016-0060

Geng, R., Bose, I., \& Chen, X. (2015). Prediction of financial distress: An empirical study of listed Chinese companies using data mining. European Journal of Operational Research, 241(1), 236247. https://doi.org/10.1016/j.ejor.2014.08.016

Ghadas, A., Ismail, W., Aziz, A., \& Rahman, A. (2015). SOCIAL SCIENCES \& HUMANITIES LAFAMS : Account Management System for Malaysian Small Legal Firms. Pertanika J. Soc. Sci. \& Hum, 23, 239-250.

Hamid, N. A., Aisyah, H., Taib, M., Noor, R., Yaacob, Z., Shamsuddin, R., ... Afthanorhan, A. (2018). The Effect of Tax Reforms on Tax Agents' Job Burnout in Malaysia The Effect of Tax Reforms on Tax Agents ' Job Burnout in Malaysia. International Journal of Academic Research in Business and Social Sciences, 8(12), 547-560. https://doi.org/10.6007/IJARBSS/v8-i12/5054

Huseynov, F., Sardarli, S., \& Zhang, W. (2017). Does index addition affect corporate tax avoidance? Journal of Corporate Finance, 43(1), 241-259. https://doi.org/10.1016/j.jcorpfin.2017.01.008

Ismail, M., Zainol, F. A., Norhayate, W., Daud, W., Rashid, N., \& Afthanorhan, A. (2018). Application of Entrepreneurial Marketing to the Marketing Mix : Why it Matters to SMEs in Malaysia? 
INTERNATIONAL JOURNAL OF ACADEMIC RESEARCH IN BUSINESS AND SOCIAL SCIENCES Vol. 8, No. 11, Nov, 2018, E-ISSN: 2222-6990 @ 2018 HRMARS

Application of Entrepreneurial Marketing to the Marketing Mix : Why it Matters to SMEs in Malaysia ? International Journal of Academic Research in Business and Social Sciences, 8(12), 850-865. https://doi.org/10.6007/IJARBSS/v8-i12/5079

Ismail, W. S. W., Ali, A., \& Rashid, N. M. N. N. M. (2017). Does Adoption of CAIS differentiate the SMEs Performance: Evidence in Malaysia. World Applied Sciences Journal, 35(9), 1981-1985. https://doi.org/10.5829/idosi.wasj.2017.1981.1985

Jiang, H., Habib, A., \& Zhou, D. (2015). Accounting restatements and audit quality in China. Advances in Accounting, 31(1), 125-135. https://doi.org/10.1016/j.adiac.2015.03.014

Johari, R. J., Rashid, N., \& Yazid, A. S. (2018). An Empirical Examination of Undergraduate Accounting Students' Ethical Judgment : Malaysia Evidence An Empirical Examination of Undergraduate Accounting Students ' Ethical Judgment : Malaysia Evidence. International Journal of Academic Research in Business and Social Sciences, 8(12), 669-681. https://doi.org/10.6007/IJARBSS/v8-i12/5064

Johari, R. J., Tarmizi, M., Mohd, H., \& Rashid, N. (2018). A Revisited Note on Internal Audit Function and Good Corporate Governance A Revisited Note on Internal Audit Function and Good Corporate Governance. International Journal of Academic Research in Business and Social Sciences, 8(12), 716-728. https://doi.org/10.6007/IJARBSS/v8-i12/5067

Khan, M. J., Hussain, D., \& Mehmood, W. (2016). Why do Firms Adopt Enterprise Risk Management (ERM)? Empirical Evidence from France. Management Decision, 54(8), 1886-1907. https://doi.org/http://dx.doi.org/10.1108/MD-09-2015-0400

Kraft, A. (2015). Management Earnings Forecasts and Book-Tax Differences. International Journal of Economics and Finance, 7(3), 1-24. https://doi.org/10.5539/ijef.v7n3p1

Kurniasih, C. E., Nasir, M., Mahmud, M. S., Rashid, N., Ghazali, P. L., \& Afthanorhan, A. (2018). Analysis of the Relationship between World Oil Price and Exchange Rate on Agricultural Commodity Prices in Indonesia Analysis of the Relationship between World Oil Price and Exchange Rate on Agricultural Commodity Prices in Indonesia. International Journal of Academic Research in Business and Social Sciences, 8(12), 561-576. https://doi.org/10.6007/IJARBSS/v8-i12/5055

Lassoued, N., Ben Rejeb Attia, M., \& Sassi, H. (2017). Earnings management and ownership structure in emerging market: Evidence from banking industry. Managerial Finance, 43(10), 1117-1136. https://doi.org/10.1108/MF-11-2015-0312

Liu, S. (2018). Earnings management and institutional investor trading prior to earnings announcements. China Finance Review International, CFRI-01-2018-0010. https://doi.org/10.1108/CFRI-01-2018-0010

Martins, A. (2017). Tax avoidance, anti-abuse clauses and arbitration courts: A note on capital gains' exemption. International Journal of Law and Management, 59(6), 804-825. https://doi.org/10.1108/IJLMA-05-2016-0050

Norliana, A. M., Fakhrul Anwar, Z., Wan Norhayate, W. D., Norfadzilah, R., \& Asyraf, A. (2018). Entrepreneurial Intention from the Islamic Perspective : A Holistic Approach Entrepreneurial Intention from the Islamic Perspective : A Holistic Approach. International Journal of Academic Research in Business and Social Sciences, 8(12), 820-833. https://doi.org/10.6007/IJARBSS/v8i12/5077 
INTERNATIONAL JOURNAL OF ACADEMIC RESEARCH IN BUSINESS AND SOCIAL SCIENCES Vol. 8, No. 11, Nov, 2018, E-ISSN: 2222-6990 @ 2018 HRMARS

Rashid, N., Fara, N., Kamal, S., Hamid, N. A., Ghazali, N., Yusop, R., ... Abd, N. (2018). The Effect of Government Support Programs and Compliance Costs on Goods and Services Tax Compliance among Malaysian Batik Manufacturers The Effect of Government Support Programs and Compliance Costs on Goods and Services Tax Compliance among Malaysian Bat. International Journal of Academic Research in Business and Social Sciences, 8(12), 682-694. https://doi.org/10.6007/IJARBSS/v8-i12/5065

Rashid, N. M. N. N. M., Harman, M. H., Sulaiman, Z., Rahman, K. A., Sharifah, M., \& Alaudeen, S. (2017). Embracing Islamic Microfinance : Proposed Role of Mosque Institution in Malaysia in Providing Qardhul Hasan Microcredit. World Applied Sciences Journal, 35(9), 1986-1993. https://doi.org/10.5829/idosi.wasj.2017.1986.1993

Rashid, N. M. N. N. M., Malik, M. F., Noor, R., Sanusi, Z. M., \& Hamid, N. A. (2017). Effective Tax Rates of Shariah Compliant Companies : Importance of Tax Related Expenses and Zakat Contribution. World Applied Sciences Journal, 35(8), 1636-1640. https://doi.org/10.5829/idosi.wasj.2017.1636.1640

Rashid, N. M. N. N. M., Muhmad, S. N., Hamid, N. A., Rasit, Z. A., \& Noor, R. (2017). Sustainability of Camel Framework as A Performance Evaluator For Banking Industry. World Applied Sciences Journal 35, 35(9), 1839-1843. https://doi.org/10.5829/idosi.wasj.2017.1839.1843

Rashid, N. M. N. N. M., Noor, R. M., \& Mastuki, N. A. (2015). SOCIAL SCIENCES \& HUMANITIES Longitudinal Study of Corporate Tax Planning : Analysis on Companies ' Tax Expense and Financial Ratios. Pertanika Journal of Social Sciences \& Humanities, 23((S)), 109-120.

Rashid, N. M. N. N. M., Noor, R. M., Matsuki, N., AbRahman, N. A., \& Omar, N. (2016). The Longitudinal Study of Earnings Management: Analysis on Companies Financial Abilities. Procedia Economics and Finance, 35(16), 136-145. https://doi.org/10.1016/S22125671(16)00018-6

Rashid, N. M. N. N. M., Rasit, Z. A., Syazwani, L., Hamid, N. A., \& Yazid, A. S. (2017). Management Accounting Systems ( MAS ) Adoption : Empirical Evidence from Malaysian Manufacturing Companies. World Applied Sciences Journal 35, 35(9), 1907-1917. https://doi.org/10.5829/idosi.wasj.2017.1907.1917

Rashid, N., Muhmad, S. N., Hassan, M., Haat, C., Muhmad, S. N., Hashim, H. A., \& Afthanorhan, A. (2018). Risk Management Effectiveness Index Score for Pre and Post Malaysian Code on Corporate Governance 2012 Risk Management Effectiveness Index Score for Pre and Post Malaysian Code on Corporate Governance. International Journal of Academic Research in Business and Social Sciences, 8(12), 729-741. https://doi.org/10.6007/IJARBSS/v8-i12/5068

Riwayati, H. E., Markonah, \& Siladjaja, M. (2016). Implementation of Corporate Governance Influence to Earnings Management. Procedia - Social and Behavioral Sciences, 219, 632-638. https://doi.org/10.1016/j.sbspro.2016.05.044

Sabiu, I. T., Zainol, F. A., Norhayate, W., Daud, W., Rashid, N., Afthanorhan, A., ... Zainol, F. A. (2018). Big Five Personality Characteristics : An Exploratory Study on Bumiputra SMEs in Malaysia Big Five Personality Characteristics : An Exploratory Study on Bumiputra SMEs in Malaysia. International Journal of Academic Research in Business and Social Sciences, 8(12), 866-881. https://doi.org/10.6007/IJARBSS/v8-i12/5080

Salleh, F., Ibrahim, M. D., Yazid, A. S., Afthanorhan, A., Rashid, N., \& Ghazali, P. L. (2018). Micro 
INTERNATIONAL JOURNAL OF ACADEMIC RESEARCH IN BUSINESS AND SOCIAL SCIENCES Vol. 8, No. 11, Nov, 2018, E-ISSN: 2222-6990 @ 2018 HRMARS

Small and Medium Enterprise Demand for General Takaful : Proposed Theoretical Framework and Hypotheses Development Micro Small and Medium Enterprise Demand for General Takaful : Proposed Theoretical Framework and Hypotheses Development. International Journal of Academic Research in Business and Social Sciences, 8(12), 599-612. https://doi.org/10.6007/IJARBSS/v8-i12/5058

Salleh, F., Noor, D., Ag, H., Yazid, A. S., Salleh, F., Noor, D., ... Rashid, N. (2018). Consumer Behaviour and Insurance Claim Fraud in Malaysia Consumer Behaviour and Insurance Claim Fraud in Malaysia. International Journal of Academic Research in Business and Social Sciences, 8(12), 586-598. https://doi.org/10.6007/IJARBSS/v8-i12/5057

Sax, J., \& Torp, S. S. (2015). Speak up! Enhancing Risk Performance with Enterprise Risk Management, Leadership Style and Employee Voice. Management Decision, 53(7), 1452-1468. https://doi.org/http://dx.doi.org/10.1108/MD-10-2014-0625

Shams, A., Hoque, M. M., Awang, Z. Bin, Muda, H., Salleh, F., \& Rashid, N. (2018). Ramification of crowdfunding on Bangladeshi entrepreneur's self-efficacy. International Journal of Academic Research in Business and Social Sciences, 8(12), 129-138. https://doi.org/10.5267/j.ac.2018.04.001

Sundvik, D. (2017). Tax-induced fiscal year extension and earnings management. Journal of Applied Accounting Research, 18(3), 356-374. https://doi.org/10.1108/JAAR-06-2015-0051

Toerien, F., \& Marcus, M. (2014). The Effect Of South African Dividend And Capital Gains Taxes On Share Prices And Investor Expected Returns. The Journal of Applied Business Research, 30(3), 895-909.

Usop, R., Zainol, F. A., Chik, Z., Norhayate, W., Daud, W., Rashid, N., \& Afthanorhan, A. (2018). Competitive Advantage and Performance : Empirical Investigation on Demographic Factors of Malaysian Hotel Entrepreneurs Competitive Advantage and Performance : Empirical Investigation on Demographic Factors of Malaysian Hotel Entrepreneurs. International Journal of Academic Research in Business and Social Sciences, 8(12), 810-819. https://doi.org/10.6007/IJARBSS/v8-i12/5067

Yazid, A. S., Ariffin, J., Awang, Z., Daud, W. N. W., Zainol, F. A., Salleh, F., ... Hamid, N. A. (2017). Does Education Moderates the Relationship Between Decision Factors and Purchase Decision of Family Takaful Protection in Malaysia ? World Applied Sciences Journal, 35(9), 1849-1863. https://doi.org/10.5829/idosi.wasj.2017.1849.1863

Yazid, A. S., Jais, W. M., Jusoh, M. S., Norhayate, W., Daud, W., Salleh, F., ... Hamid, N. A. (2017). Islamic Personal Risk Management from Islamic Perspective. World Applied Sciences Journal 35, 35(9), 1885-1892. https://doi.org/10.5829/idosi.wasj.2017.1885.1892

Zain, F. A. M., Abdullah, W. A. W., \& Rashid, N. (2018). The Mediating Role of Environmental Performance on The Relationship Between Corporate Governance Mechanisms and Environmental Disclosure. Asian Academy of Management Journal of Accounting and Finance, 14(1), 153-183. https://doi.org/10.21315/aamjaf2018.14.1.7

Zainol, F. A., Aik, C. K., Muthmainnah, N., Hadi, H., Norhayate, W., Daud, W., ... Muthmainnah, N. (2018). Food Security and Food Value Chain : Identifying the Influencing Components in Malaysian Seed Industry Food Security and Food Value Chain : Identifying the Influencing Components in Malaysian Seed Industry. International Journal of Academic Research in 
INTERNATIONAL JOURNAL OF ACADEMIC RESEARCH IN BUSINESS AND SOCIAL SCIENCES Vol. 8, No. 11, Nov, 2018, E-ISSN: 2222-6990 @ 2018 HRMARS

Business and Social Sciences, 8(12), 834-849. https://doi.org/10.6007/IJARBSS/v8-i12/5078 Zhang, Z. (2015). Under-Performance of Listed Companies, Real Earnings Management and M \& A : Chinese Empirical Evidence. Journal of Industrial Engineering and Management, 8(2), 322-334. 